
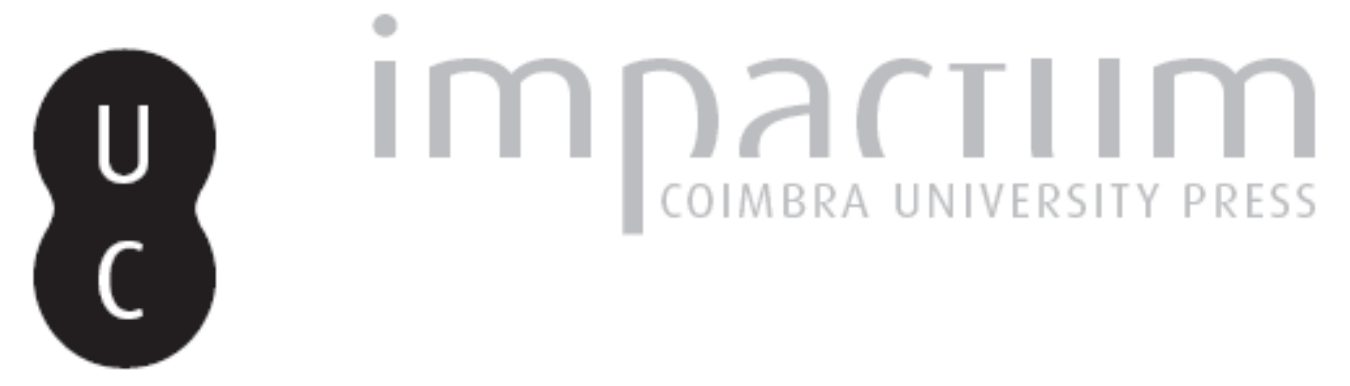

Redinha (Pombal): subsídios para a carta arqueológica da freguesia

Autor(es): $\quad$ Aubry, Thierry; Moura, Maria Helena

Publicado por: Imprensa da Universidade de Coimbra

URL persistente:

URI:http://hdl.handle.net/10316.2/45543

DOI:

DOI:https://dx.doi.org/10.14195/1647-8657_29_1

Accessed : $\quad$ 26-Apr-2023 13:58:07

A navegação consulta e descarregamento dos títulos inseridos nas Bibliotecas Digitais UC Digitalis, UC Pombalina e UC Impactum, pressupõem a aceitação plena e sem reservas dos Termos e Condições de Uso destas Bibliotecas Digitais, disponíveis em https://digitalis.uc.pt/pt-pt/termos.

Conforme exposto nos referidos Termos e Condições de Uso, o descarregamento de títulos de acesso restrito requer uma licença válida de autorização devendo o utilizador aceder ao(s) documento(s) a partir de um endereço de IP da instituição detentora da supramencionada licença.

Ao utilizador é apenas permitido o descarregamento para uso pessoal, pelo que o emprego do(s) título(s) descarregado(s) para outro fim, designadamente comercial, carece de autorização do respetivo autor ou editor da obra.

Na medida em que todas as obras da UC Digitalis se encontram protegidas pelo Código do Direito de Autor e Direitos Conexos e demais legislação aplicável, toda a cópia, parcial ou total, deste documento, nos casos em que é legalmente admitida, deverá conter ou fazer-se acompanhar por este aviso.

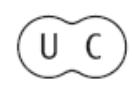


FACULDADE DE LETRAS

INSTITUTO DE ARQUEOLOGIA

CONIMBRIGA

VOLUME XXIX

UNIVERSIDADE DE COIMBRA

1990 


\title{
THIERRY AUBRY
}

Do Instituto do Quaternário da Universidade de Bordéus I.

\author{
MARia Helena MoUra
}

Licenciada em Arqueologia.

REDINHA (POMBAL) -

SUBSÍDIOS PARA A CARTA ARQUEOLÓGICA DA FREGUESIA

"Conimbriga", XXIX, 1990, 5-37

RESUMO: As prospecções realizadas a partir de uma área surribada para a plantação de pinheiros, na freguesia da Redinha (Pombal), mostram uma forte densidade de ocupação do território atribuível ao Paleolítico, sobretudo nas fases correspondentes aos períodos Antigo e Médio, e ao Neolítico, sendo os vestígios da época romana mais raros.

O sector intermediário, entre o vale da Ribeira de Anços, a menos de 50 metros de altitude, e o planalto de Degracias-Alvorge, situado a cota superior a 350 metros, constitui uma zona favorável à implantação humana, uma vez que estão associados, numa pequena superfície do território, domínios ecológicos variados.

A descoberta de um abrigo calcário gravado, no Vale do Poio Novo, é um dado original, actualmente sem equivalência em Portugal e que merece um estudo aprofundado.

Este trabalho preliminar mostra igualmente que escavações de emergência deveriam ser realizadas, em jazidas de ar livre e de gruta, ameaçadas de destruição.

RÉSUMÉ: Des prospections réalisées à partir d'une zone préparée pour la plantation de pins sur la commune de Redinha (Portugal), ont mis en évidence une forte densité d'occupations attribuables au Paléolithique Ancien, Moyen, Supérieur, Néolithique. Les vestiges d'époque romaine présentent une densité considérablement plus faible.

Ce secteur, intermédiaire entre la vallée de la rivière Anços à moins de 50 mètres d'altitude et le plateau de Degracias-Alvorge (supérieur à 350 mètres), constitue une zone favorable à l'implantation où sont associés sur une faible superficie des domaines écologiques variés.

La découverte d'un abri calcaire gravé dans la vallée du Poio Novo est une donnée originale, actuellement sans équivalent au Portugal, qui mériterait une étude plus poussée. Ce travail préliminaire montre également que des sondages devraient être réalisés sur des gisements de plein air et de grotte menacés de destruction. 
(Página deixada propositadamente em branco) 


\section{REDINHA (POMBAL) SUBSÍDIOS PARA A CARTA ARQUEOLÓGICA DA FREGUESIA*}

\section{I - Introdução}

\section{1-Condicionalismos da pesquisa}

Este trabalho é fruto de uma prospecção de emergência realizada em parte da área inicialmente prevista. O repovoamento florestal de parte da freguesia da Redinha, iniciado no inverno de 1990, levou-nos a iniciar na Primavera seguinte a prospecção da zona a reflorestar. A prospecção, aqui dada a conhecer, só viria a ser concluída no fim do Verão do mesmo ano.

O carácter urgente desta primeira fase do trabalho não permitiu uma preparação prévia que incluísse os levantamentos toponímico e bibliográfico.

A batida de campo não foi feita segundo uma malha homogénea, pois privilegiámos a zona destinada ao futuro pinhal, bem como uma

\section{* AGRADECIMENTOS:}

Gostaríamos de expressar a nossa gratidão à população dos Poios, pela receptividade com que acolheu este trabalho. À família Rodrigues, que amavelmente nos hospedou, proporcionando as condições que nos permitiram um bom ritmo de trabalho, ficamos imensamente reconhecidos.

Aos Doutores Susana e Vítor Oliveira Jorge, agradecemos a classificação das cerâmicas provenientes das jazidas pré-romanas da nossa prospecção e ainda os conselhos e advertências relativamente ao abrigo ornado.

O Doutor José d'Encamaçâo fez-nos sugestões muito proveitosas aquando da redacção deste artigo, pelo que lhe estamos reconhecidos.

Estamos particularmente gratos ao Professor Jorge de Alarcão que nos fez oportunas correcções, bem como sugestões muito profícuas. Devemos-lhe, ainda, a classificação das cerâmicas provenientes do local denominado Pelónia. 
pequena área envolvente. A superfície do território em que se pretende fazer o repovoamento florestal correspondente grosso modo aos locais denominados de Poio Novo e de Poio Velho, abrangendo a área que se entrepõe entre estes e que na nossa carta se situa na zona onde se encontram as estações arqueológicas numeradas de 20 a 25.

Os resultados da prospecção estão directamente dependentes do revestimento vegetal e do tipo de lavras efectuadas nos terrenos. As terras, em poisio há um longo período de tempo, apresentam mato denso ao ponto de dificultar a marcha e impedir a visão de quaisquer vestígios arqueológicos. Noutros locais, os poisios datam de há menos tempo e a vegetação rasteira permite a prospecção, mas os vestígios arqueológicos são raros tratando-se, por vezes, apenas de objectos isolados. Os sítios a que atribuímos os números $4,9,10,26$ e 29 correspondem a esta situação, o que nos impede de propor uma cronologia para os objectos aí encontrados. Efectivamente, foi nos campos lavrados que se fizeram os achados mais abundantes, havendo ainda a registar uma diferença sensível entre as lavras mecânicas e os terrenos cavados à enxada. Assim, alguns dos "vazios" da nossa carta arqueológica podem resultar da impossibilidade de prospecção, ou do facto de a vegetação, mesmo rasteira, esconder os vestígios arqueológicos.

Durante os trabalhos de campo* ainda nos deparámos com outra dificuldade relacionada com a impossibilidade de acesso a pequenas galerias do karst por falta de equipamento de Espeleología.

\section{2 - Ficha de inventário}

Para o inventário das estações procurámos elaborar uma ficha simples, de consulta rápida e que reunisse o máximo de informações.

$\mathrm{O}$ item que concerne à caracterização e contabilização dos materiais levantou alguns problemas que não conseguimos resolver inteiramente. De facto, efectuámos uma diferenciação dos objectos que não permite a classificação tipológica dos mesmos. Isto é: agrupámos todos os vestígios segundo o critério das matérias-primas, não discriminando a tipologia dos mesmos. Esta situação é o resultado de termos elaborado a ficha em computador e de, por necessidade de execução rápida, termos optado por reduzir ao mínimo o número de campos deste item da ficha. Outro dos problemas é o de não referirmos se os objectos se encontram inteiros ou fragmentados. Ainda aqui é válido o argumento da proliferação dos campos descritivos dos objectos arqueológicos. 
Alguns dos materiais não foram quantificados. São normalmente objectos de que não encontrámos senão fragmentos e que carecem de um estudo mais aprofundado, e eventualmente, de colagens. Encontram-se neste caso os vestígios osteológicos, as conchas marinhas, as placas de hematite. Também não quantificámos os fragmentos de tegulae, imbrices ou lateres, por serem muito abundantes.

Não abrimos um item destinado à identificação do local de depósito dos materiais arqueológicos que encontrámos, porque eles estão provisoriamente em nosso poder. Dos materiais exumados em escavações das grutas I e II do Ourão, apenas os vestígios osteológicos se encontram connosco, estando os restantes em poder dos responsáveis pelas escavações. Os objectos referidos nas estações números 3 e 7 , de que apenas tomámos conhecimento pela bibliografia, encontram-se dispersos, tendo alguns deles dado entrada no Museu da Figueira da Foz (estão neste caso os machados polidos que A. dos Santos Rocha recolheu na região, bem como os vestígios osteológicos provenientes do "silo" de Caeiros dos Algarves) e outros estando de posse do Sr. Presidente da Junta de Freguesia da Redinha, segundo informação de M. F. F. Cordeiro (CORDEIRO, 1984, p. 163-169) que fotografou vários pondera. Ainda segundo a mesma fonte, há moedas romanas provenientes da Roda, que foram levadas para Lisboa.

O mesmo topónimo foi frequentemente utilizado em diferentes estações arqueológicas por desconhecimento dos microtopónimos. Esta situação deve-se ao facto de não termos realizado um levantamento toponímico prévio e, sobretudo, de não termos encontrado quem nos fornecesse essas informações, aquando das prospecções.

Utilizamos as coordenadas U. T. M.

\section{II - Geomorfologia}

A área agora prospectada, não sendo uma unidade geográfica bem determinada, situa-se na confluência de um mosaico de micro-regiões, geográfica e geomorfologicamente distintas entre si, constituindo um nicho ecológico variado.

Do ponto de vista geomorfológico, a região objecto deste trabalho identifica-se com a vertente ocidental do planalto de Degracias-Alvorge/ escarpa da Senhora da Estrela. 
O Doutor Lúcio José S. da Cunha, no seu estudo geomorfológico das serras calcárias de Condeixa-Sicó-Alvaiázere (CUNHA, 1988, p. 78-81 e 282) interpretou a região como sendo um acidente principal a que corresponde a escarpa mais importante da Senhora da Estrela e Costa do Alvito e como uma escadaria tectónica complexa que faz a ligação com as baixas colinas situadas a ocidente do Rio Anços.

O limite ocidental do planalto que coincide com a linha limítrofe oeste da nossa prospecção, caracteriza-se pelo confinar dos calcários do Dogger.

O Batoniano e o Bajociano foram difíceis de distinguir de um ponto de vista litològico, bem como de nível geológico, e possuem silicificações de volume por vezes importante, como é o caso de Vale da Sorsa. As silicificações, sob forma de nódulos irregulares, e de tamanhos por vezes superiores a cinquenta centímetros, apresentam cristalizações variáveis e de diferentes qualidades de grão e foram utilizadas pelas populações pré-históricas. Os depósitos detríticos terciários ou cretácicos, existentes em toda a superfície prospectada, foram igualmente utilizados para a extracção de seixos de quartzo e de quartzite.

A presença de matérias-primas siliciosas na zona intermédia entre a falha principal e o Rio Anços, foi provavelmente um polo importante de ocupação humana e pode explicar a elevada densidade de estações arqueológicas do Paleolítico.

As indústrias líticas descobertas não fornecem dados cronológicos novos no que concerne aos depósitos detríticos estudados pelo Doutor Lúcio Cunha na obra acima referida.

\section{III — As estações arqueológicas}

\section{III - 1. Paleolítico Antigo e Médio}

A comprovar a ocupação humana desta pequena parcela do território, durante o Paleolítico Antigo e Médio, encontrámos várias estações arqueológicas. São elas correspondentes aos pontos números: 6; 8 (Est. IX); 13 (Est. VII); 21 (Est. Vili); 22; 23 (Est. VI); 24 e 28 da nossa carta. A estas poderão, eventualmente, vir a juntar-se outras, no caso de num futuro próximo virmos a encontrar fósseis directores em alguns dos locais onde, até agora, na ausencia de peças típicas, apenas registámos a exis- 
tènda de vestígios os quais aparecem na nossa carta associados ao símbolo indeterminado.

Merece um reparo o facto de todas as jazidas corresponderem a locais de ar livre, embora não seja impossível que os estratos mais profundos das grutas venham a revelar ocupações antigas.

As estações que numerámos de 21 a 24 encontram-se ameaçadas de destruição pelo repovoamento florestal previsto para esta área. A realizarem-se, as escavações de emergência poderão permitir um melhor conhecimento das tipologías e mesmo afinar as cronologias relativas destes dois períodos do Paleolítico que, numa recolha de superfície, achámos conveniente juntar. Em alguns casos, as séries encontram-se muitíssimo roladas e isso permite pensar que são as mais antigas; contudo, a ausência de estudos estratigráfícos e o desconhecimento absoluto das condições de jazida impedem-nos de fundamentar assim uma tal distinção cronológica.

\section{III — 2. Paleolítico Superior}

A presença do homem durante o Paleolítico Superior deixou vestígios em dois locais, assinalados com os números 2 e 16.

Desde o início da década de 80 que se deram a conhecer os vestígios solutrenses da gruta do Ourão (RIBEIRO, J. C., 1982). Esta jazida é ainda referida por (CORDEIRO, 1984, p. 158-162). As escavações, no entanto, não puderam identificar o local exacto de proveniência dos materiais líticos, mas admitiu-se que seria impossível fazê-lo corresponder à galeria do karst que então se escavou (informação que devemos aos responsáveis pelas escavações).

As escavações realizadas numa galeria superior, a que se chamou Ourão II *, revelaram que esta foi utilizada como sepultura colectiva, durante a Pré-história Recente. Não se escavaram, porém, todos os níveis até à rocha, em toda a superfície das sondagens e, portanto, não estão esgotadas as hipóteses de averiguação da ocupação, durante o Paleolítico Superior. As prospecções agora efectuadas, na superfície do pequeno maciço calcário onde se abrem as grutas, forneceram um conjunto de peças líticas que apresentam fortes semelhanças com os objectos

\footnotetext{
* Agradecemos estas informações aos responsáveis das escavações, uma vez que se encontram ainda inéditas.
} 
do solutrense exumados na galena inferior do karst. No locai prepara-se uma plantação de pinheiros, pelo que a jazida de ar livre se encontra ameaçada de destruição. Escavações de emergência poderiam confirmar a suposição que avançamos, a título de hipótese de trabalho, de que a ocupação do solutrense corresponde a um habitat de ar livre; as peças primeiramente encontradas poderiam ter migrado para a gruta I por infiltração. Esta hipótese não exclui, contudo, a utilização da rede karstica para outros fins.

Pensamos que será lícito considerar duas estações diferentes neste local: a superfície do maciço, local de proveniência dos objectos líticos que se encontraram agora, e a galeria, denominada Ourão II, onde foi parcialmente escavada uma sepultura colectiva datável da Pré-história Recente.

A Buraca Grande (n. $\left.{ }^{\circ} 16\right)$, gruta que ocupa uma situação destacada no Vale do Poio Novo e que oferece um espaço suficientemente amplo para habitat, também foi ocupada durante o Paleolítico Superior. Os materiais que recolhemos à superfície são prova disso (Est. IV e V). Eles encontram-se, porém, misturados com outros, mais recentes: cerâmicas (Est. Ill, $\mathrm{n}^{\circ}$ 13), vestígios osteológicos de fauna e humanos, o que nos interdita, para já, de pretender atribuir uma cronologia mais precisa, uma vez que parte dos objectos líticos podem ser provenientes da ocupação datável da Pré-história Recente.

Esta gruta tem a sua jazida arqueológica ameaçada de destruição, aliás já iniciada quando vieram aqui buscar terras "férteis" para os campos de batatas. Ela é muito frequentada por pastores e respectivos rebanhos, bem como por caçadores, espeleólogos e praticantes de montanhismo. Em alguns locais, o paleossolo encontra-se desprotegido, uma vez que os sedimentos mais móveis foram retirados. Só poderemos avaliar os prejuízos através da observação de cortes estratigráficos. A parte mais profunda da gruta não parece ter sofrido alterações aquando da extracção, pois aí não se pode andar em pé e talvez ainda exista a hipótese de recuperar a estratigrafía original da jazida.

Das várias jazidas arqueológicas a que não considerámos prudente atribuir uma cronologia precisa, algumas poderão vir a aumentar o número de estações datáveis deste período mais recente do Paleolítico. 


\section{3 - A Pré-história Recente}

As jazidas arqueológicas números 2, 14, 20 (Est. Ill, n. ${ }^{\circ s} 8$ a 11), 21 (Est. Ill n. ${ }^{\circ} 1$ a 7) 22, 23, 24, 25 e 27, que pertencem à Pré-história forneceram em alguns casos um número importante de objectos arqueológicos. A primeira destas, chamada gruta II do Ourão, é uma sepultura colectiva, onde se efectuaram duas campanhas de escavações. Os ossos encontram-se em nosso poder, mas o seu estudo não está concluído. Durante as prospecções verificámos que alguns vestígios osteológicos estão à vista e esta situação pode contribuir para a destruição do que resta desta jazida arqueológica.

Outras estações arqueológicas do mesmo período cronológico são de ar livre. Muitas delas situam-se na área destinada a repovoamento florestal, estando entre estas as numeradas de 20 a 25. Escavações de emergência poderiam fornecer, mais uma vez, elementos decisivos para a interpretação deste tipo de ocupação do território que se traduz por uma tão elevada concentração de vestígios.

O local assinalado sob o n. 27 apenas forneceu um fragmento de machado polido, mas decidimos cartografá-lo porque a prospecção foi aqui rápida, e como se situa na área periférica do futuro pinhal, contamos refazer a batida de campo. Em toda a prospecção, os machados polidos foram sempre achados em contextos arqueológicos coerentes, razão que justifica, pensamos, a cartografia desta estação.

A Buraca Grande, onde se encontraram os materiais representados nas estampas II, III e IV, forneceu um fragmento de cerâmica cuja cronologia poderá ser atribuída ao campaniforme. A recolha de superfície não permite interpretar correctamente o sítio que também foi frequentado no Paleolítico, e que, entre outros materiais, forneceu ossos humanos. Talvez os materiais datáveis da Pré-história Recente estejam relacionados com as sepulturas.

\section{III. $4-$ Romano}

A existência de vestígios romanos na zona agora prospectada é reconhecida de há muito. A estação da Roda foi objecto de uma primeira referência datada de 1908 (ROCHA, 1908c) e posteriormente outros autores se lhe referem: (ALARCÃO, 1988) e (CORDEIRO, 1984). Na nossa carta ela recebeu o n. ${ }^{\circ} 3$, mas apenas tomámos conhecimento da sua 
existencia através da bibliografia. A esta, podemos agora juntar outras, que cartografámos com os números $1,5,6,11$ e 12. Cumpre-nos dizer que, não tendo feito nenhum levantamento toponímico prévio, apenas nos limitámos a cartografar os vestígios que encontrámos aquando das prospecções. Destas, as jazidas números 1 e 6 estão ameaçadas de destruição, ambas pela abertura recente de estradas.

Segundo SAA (1956), um ramal secundário de uma via romana passaria nesta zona; a toponímia é também sugestiva neste sentido, mas o carácter urgente deste trabalho não nos permitiu procurar os seus vestígios.

III. 5 - Indeterminado.

Doze das jazidas agora cartografadas não puderam ser cronologicamente classificadas por falta de artefactos típicos. Em alguns casos, a recolha de superfície não pôde reunir senão alguns objectos incaracterísticos. Noutros casos há materiais abundantes mas não se encontraram fósseis directores.

Em nove destes locais todos os objectos recolhidos são líticos, o que poderá vir a aumentar o número de jazidas atribuíveis ao Paleolítico.

A Buraca Escura (n. $\left.{ }^{\circ} 19\right)$ forneceu vestígios osteológicos que permitem identificar aqui uma jazida paleontológica interessante, mas não foi ainda achado qualquer vestígio arqueológico.

Sob o n. 7 e associado ao símbolo indeterminado, encontrou-se uma estrutura arqueológica (RоснA, 1908a) que talvez possa ser datada do Neolítico, mas Santos Rocha admitiu a possibilidade de se tratar de um achado do Calcolitico (op. cit. p. 196). Tivemos conhecimento desta jazida arqueológica através da bibliografia e ainda não prospectámos o local. Aliás, M. F. Cordeiro diz não ter encontrado o microtopónimo Caeiros dos Algarves (CORDEIRO, 1984, p. 184). Pensamos que ele se simplificou e que poderá corresponder a Caeiro que ainda aparece na carta Militar 1: 25000 editada pelos Serviços Cartográficos do Exército em 1947, junto do geodésico da Redinha. Esta situação está de acordo com a localização dada por Santos Rocha (op. cit. p. 197). Este investigador parece admitir que o achado se pode interpretar como uma sepultura colectiva escavada na rocha, embora nunca use este termo. Afirma, no entanto, que o silo se assemelha aos de Acébuchal e Campo Real e que estes são sepulturas colectivas. $\mathrm{O}$ achado de ossos humanos (nomea- 
damente de um húmero imaturo) com características que considera semelhantes às dos vestígios osteológicos provenientes dos dólmens, vem corroborar a hipótese de se tratar, de facto, de uma sepultura colectiva escavada na rocha. A estrutura, escavada no calcário brando, era campaniforme e estava já muito destruída quando $d$ investigador figueirense visitou o local. Pôde ainda constatar que as paredes foram escavadas com "herminettes de pedra ou com machados chatos de pedra ou cobre" (op. cit. p. 198). Fez igualmente a constatação de que o monumento fora descoberto e despojado da quase totalidade do seu conteúdo bem como novamente fechado por intermédio de uma mó de pedra, mas na Redinha ninguém tinha já memória do sucedido e, na interpretação popular, o "silo" fora esconderijo feito na época das invasões francesas. Para além de alguns vestígios osteológicos, que $\mathbf{S}$. Rocha examinou, não há notícia de quaisquer outros achados arqueológicos. H. N. Savory (SAVORY, 1968) cartografa esta jazida arqueológica (p. 119, carta n. ${ }^{\circ} 37$ ), classificando-a de "túmulo escavado na rocha tipo silo". No texto, no entanto, não se lhe refere e não indica a sua fonte bibliográfica. Pensamos que é legítima a interpretação dada por este autor.

$\mathrm{O}$ n. ${ }^{\circ} 14$ da nossa carta corresponde a toda a vertente norte do Vale do Poio Novo, onde os achados arqueológicos são abundantes. No entanto, as cerâmicas são representadas por fragmentos extremamente pequenos, frequentemente provenientes de peças não torneadas, embora alguns sejam manifestamente recentes. Encontrámos, igualmente, materiais Uticos: alguns sílices talhados e retocados, quartzitos talhados e um machado de pedra polida (Est. Ill $\mathrm{n} .^{\circ}$ 12). Informaram-nos no local que antigamente se cultivaram batatas nesta encosta do vale. Talvez se encontre aqui a explicação para o facto de os achados serem feitos numa superfície tão extensa e simultaneamente para o estado extremamente fragmentário dos materiais.

\section{IV - Abrigo sob rocha ornado com gravuras}

Abrigo sob rocha situado no segundo nível geológico do Vale do Poio Novo, corresponde, na nossa carta, ao local assinalado com o número 18 associado ao símbolo indeterminado. A "pala" é suficientemente proeminente para que este se demarque da paisagem envolvente. Não há sedimentos no chão do abrigo. 
As insculturas situam-se na parede vertical virada a SE. A deseoberta destas gravuras provocou-nos alguma surpresa, pois passámos várias vezes em frente ao abrigo sem as vermos. De facto, elas não saltam imediatamente à vista a partir de qualquer dos dois caminhos de pé posto que se podem utilizar nesta zona do vale. Talvez por isso se preservaram até agora, embora já tenham sido alvo de reavivagens e de gravações recentes. Esta zona, apesar de inóspita, é muito frequentada por pastores, caçadores, espeleólogos e praticantes de montanhismo. Estes últimos são particularmente "perigosos", pois introduzem nas paredes calcárias objectos metálicos destinados a facilitarem a prática daquele desporto. $\mathrm{O}$ nosso receio de que elas venham a ser alvo de mais "grafitos" levou-nos a não indagar as populações locais sobre o microtopónimo do abrigo e impediu-nos de averiguar do conhecimento das referidas gravuras.

Não possuindo qualquer experiência neste tipo de estações arqueológicas, vários são os problemas com que nos temos deparado. Por isso, esta referência ao abrigo ornado deve entender-se como notícia do achado que integramos na carta arqueológica da freguesia da Redinha.

O levantamento que fizemos em plástico transparente, à escala 1:1, é o que apresentamos na Est. XIV. A redução foi obtida por meio de fotocópias sucessivas. Este método, que porventura não é o melhor, pois admitimos desde já não ter registado integralmente o que oferecem as superfícies historiadas, foi o único ao alcance dos nossos meios e conhecimentos.

As gravuras, tanto quanto pudemos ver, ocupam quatro painéis verticais de cor castanha clara (CAILLEUX, s.d. M 69) e também uma tonalidade de castanho alaranjado (CAILLEUX, op. cit. P 57). Este facto merece ser destacado, pois verificámos que ele se não encontra senão aqui, associado às gravuras. Prospectámos várias centenas de metros quadrados de paredes, abrigos e grutas que o karst oferece e constatámos que existem enormes superfícies coloridas em vários tons dos quais distinguimos os alaranjados (CAILLEUX, op. cit. M 45 e P 37), que se demarcam das cores mais abundantes, que são o cinzento (CAILlEUX, op. cit. P 31) e o beige claro (CAILLEUX op. cit. K 71). À superfície em que foram feitas as gravuras chama-se, vulgarmente, "couve-flor", dada a semelhança com o aspecto exterior daquele vegetal.

As insculturas foram feitas segundo técnicas diferentes, sendo as inscrições recentes a fino traço contínuo. Quase todos os motivos foram alvo de reavivagens, que podem ter tido lugar em diferentes períodos de 
tempo e que quase sempre deturpam, em maior ou menor grau, as figurações antigas. As reavivagens podem ainda ter como consequência a deturpação do tipo de técnica de gravação dos motivos originais, como nos parece ser o caso de várias das figuras.

A numeração dos painéis obedeceu ao critério seguinte: segundo a ordem em que aparecem quando percorremos o vale no sentido W-E. A nosso ver, as figurações são principalmente antropomorfos, de diferentes estilos. Eles têm em comum o facto de serem de pequenas dimensões podendo os maiores ultrapassar de pouco os 30 centímetros de altura. Alguns dos personagens parecem estar calçados de sapatos ou botas, no que encontramos semelhanças com certos antropomorfos pintados do abrigo da Fraga D'Aia, em Paredes da Beira (JORGE, V. O., et alii, 1988, p. 118, figura 8).

O carácter original deste achado, sobretudo ao nível da temática e ainda porque se trata de um abrigo gravado em domínio karstico, levanta o problema da integração deste conjunto de gravuras no complexo da arte rupestre post-glaciar, em território português. A despeito das recentes descobertas neste domínio da arqueologia nacional, e de termos percorrido grande parte da literatura dedicada à arte post-paleolítica, não pudemos encontrar paralelos para este abrigo ornado, no nosso País. Ainda assim afiguram-se lícitas as semelhanças de várias das nossas gravuras com algumas figurações provenientes de outras estações de arte rupestre. No painel 1, o motivo representado no canto superior esquerdo, a estar incompleto, seria comparável a uma das figuras do Complexo do Vale do Tejo (S. Simão), o tipo "B 10" de BaptisTA, A. M.; Martins, M. M.; SerRão, E. da C. (1978), figura 9. Imediatamente abaixo deste encontramos um antropomorfo esquemático, que nos parece idêntico ao que publica Alvaro Bobadilla (1988), figura 10 (o carácter extremamente sumário desta referência bibliográfica impedemos de saber se se trata de pinturas ou de gravuras, bem como de citar o nome do monumento de origem sabendo-se unicamente que a região de proveniência é a norte da Serra de Guadarrama). Ainda neste painel encontramos outros antropomorfos que foram integrados em orifícios naturais de contorno circular. A leitura desta parte inferior do painel é dificultada pela existência de muitas reavivagens e de deturpações várias dos motivos originais. Mesmo assim, no conjunto de gravuras do Vale da Casa (Vila Nova de Foz Côa) existe um antropomorfo semi-esquemático (BAPTISTA, A. M., 1983, p. 60, figura 5), que pode servir de paralelo aos aqui gravados. 
No painel 2 existem três figurinhas antropomórficas, diferentes entre si. Na coluna da esquerda, vemos, na parte superior, uma representação esquemática da figura humana, já parcialmente destruída, pois o membro superior esquerdo terá desaparecido. Somente a extremidade cefálica foi gravada a cheio, o corpo sensivelmente rectangular foi apenas delimitado. Abaixo deste encontra-se um antropomorfo fálico, de um estilo muito singular. A figura da coluna da direita, embora de contorno semelhante a esta última, foi gravada a cheio e apresenta no baixo ventre uma pequena depressão. Ela é comparável ao tipo "F 52" do Vale do Tejo (S. Simão) (BAPTista et alii, op. eit).

O painel 3 apenas representa urna figura humana cuja cabeça está encimada por um chapéu, capacete ou ornamento com cornos. Não temos conhecimentos de outras representações semelhantes a esta se considerarmos que no Vale da Casa (BAPTISTA, 1983, op. cit. p. 67 figura 16 e 68) e na estação de arte rupestre exterior do Escoural em Évora (Gomes, R. V.; Gomes, M. V.; Santos, M. F. 1983, p. 298) se trata de motivos esquemáticos e seguramente de bucrânios. A nossa figura não é esquemática e não levanta dúvidas quanto ao seu carácter antropomórfico mas o tipo de levantamento agora efectuado pode induzir-nos em erro, uma vez que pudemos verificar que há reavivagens antigas e que estas podem deturpar o motivo original.

O painel 4 apresenta algumas gravuras de leitura difícil. Estes motivos poderão representar os membros inferiores e o corpo de antropomorfos esquemáticos e nesse caso seriam semelhantes à figurinha humana do canto superior esquerdo do painel 2. Mas elas podem eventualmente ser interpretadas de outros modos.

\section{V — As estações arqueológicas ameaçadas de destruição}

Das vinte e seis estações arqueológicas inéditas aqui dadas a conhecer, doze encontravam-se, no período em que decorreram as prospecções (Setembro de 1990), ameaçadas de destruição. Assim, a jazida número 2 está sujeita a destruição pois parte da área de terra que cobre a superfície do maciço encontra-se preparada para a plantação de pinheiros e, na galeria II, alguns vestígios osteológicos estão à vista e à mercê de quem a frequentar. Em terrenos igualmente preparados para repovoamento florestal, encontram-se as estações numeradas de 20 a 25. 
A abertura de estradas, recentemente, constitui factor de ameaça para os locais números 1,4 e 6 . O terreno de proveniencia de materiais arqueológicos da jazida $\mathrm{n}^{\circ} 1$ está parcialmente surribado para o plantio de eucaliptos.

Duas das grutas do Vale do Poio Novo denominadas Buraca Grande e Buraca Escura, respectivamente números 16 e 19, merecem medidas de protecção, pois os vestígios jacentes encontram-se em processo de degradação. Da primeira foram levadas terras "férteis" para campos de batatas, ficando o paleossolo completamente desprotegido, numa área razoável. Sendo esta cavidade muito frequentada, urgente se torna tomar medidas que impeçam a continuação da destruição já iniciada. A Buraca Escura, onde o paleossolo se encontra parcialmente à vista, é alvo de visitas e servirá, certamente, de abrigo, pois existem fogueiras no interior.

\section{VI - Conclusões}

Vários são os períodos cronológicos que não estão representados na nossa carta: o Mesolitico, a Idade do Ferro, o Visigòtico, o Árabe. A exiguidade da parcela do terreno que prospectámos pode estar na origem destas lacunas, mas elas podem igualmente ter outras explicações. No estado actual dos nossos trabalhos, parece-nos prematuro tentar compreender o povoamento humano e o modo como se processou ao longo do tempo.

Afigura-se-nos digna de nota a grande concentração de estações arqueológicas na área onde a terra foi profundamente remexida. Isto leva-nos a pensar ser esta uma região de potencial arqueológico considerável, o que, só por si, constitui um incentivo à continuação das prospecções agora iniciadas. A existência de gravuras, com características de certo modo originais, num abrigo sob rocha do Vale do Poio Novo, parece confirmar esta ideia e dá consistência às nossas suspeitas.

Estas expectativas carecem de confirmação; porém, os resultados das escavações de emergência, que se justifica fazer antes do repovoamento florestal e do calcetamento das estradas, poderão tomar-se em elementos de avaliação mais concretos do potencial arqueológico agora sugerido, bem como fundamentar certas directrizes de trabalhos futuros. 


\section{BIBLIOGRAFIA}

ALARCÃO, J. de 1988 - Roman Portugal, II voi, fase. 2, p. 101, n. ${ }^{\circ} 185$.

ALVARO Bobadilla, E., 1988 - Nuevos grupos de arte rupestre en la meseta norte, “Arqueologia", n. ${ }^{\circ}$ 18, G.E.A.P., Porto, p. 105-109.

BAPTISTA, A. M., 1983 - O complexo de gravuras rupestres do Vale da Casa \{Vila Nova de Foz Côa), "Arqueologia", n. ${ }^{\circ}$ 8, G.E.A.P., Porto, p. 57-59.

BaptistA, A. M.; MARTINS, M. M.; SERRÃO; E. C. 1978 - Felskunst im Tejo-Tal São Simão (Nisa, Portalegre), Portugal, "Madrider Mitteilungen”, n. ${ }^{\circ} 19$, p. 89-111.

CAILlEUX, A. (s.d.) - Notice sur le code des couleurs des sols.

CUNHA, E. J. S. da, 1988 - As Serras Calcárias de Condeixa-Sicó-Alvaiázere. Estudo de Geomorfologia. Dissertação de Doutoramento em Geografia Física, Fac. de Letras, Univ. de Coimbra, p. 81 e 282.

CORDEIRO, M. F. F., 1984- Contributo para o levantamento arqueológico do concelho de Pombal. Trabalho escolar apresentado no Inst, de Arqueologia da Fac. de Letras da Univ. de Coimbra. Manuscrito.

FERREIRA, A. M. S.; LAPA, M. F. 1987 - Carta Arqueológica do Concelho de Soure. Trabalho escolar apresentado no Inst, de Arqueologia da Fac. de Letras da Univ. de Coimbra. Dactilografado.

GOMES, R. V., GOMES, M. V.; SANTOS, M. F., 1983 - O Santuário exterior do Escoural. Sector NE (Montemor-o-Novo, Évora) "Zephyrus", n. ${ }^{\circ} 36$, p. 287-307.

Jorge, V. O.; Baptista, A. M.; Jorge, S. O.; SAncheS, M. de J. Silva, E. J.; Silva, M. S.; CUNHA, A. L., 1988 - O abrigo com pinturas rupestres da Fraga D Aia (Paredes da Beira — S. João da Pesqueira)—Notícia preliminar, "Arqueologia", n. ${ }^{\circ}$ 18, G.E.A.P., Porto, p. 109-130.

Manuppella, G.; ZBysZewsKi, G; Ferreira, O. V., 1978 - Carta Geológica de Portugal, 1/50000, Notícia Explicativa da Folha 23-A.

Ribeiro, J. P. C, 1982 — ^4 indústria Utica da gruta do Ourão (Redinha, Pombal). Notícia preliminar, "Arqueologia", n. ${ }^{\circ}$ 5, G.E.A.P., Porto, p. 27-31.

ROCHA, A. dos S., 1908a - Silo préhistorico da Redinha. "Boletim da Sociedade Archeològica Santos Rocha", T. I, n. ${ }^{\circ}$ 7, Figueira da Foz, p. 196-198.

ROCHA, A. dos S. 1908b - Mobiliário neolithico esparso na freguesia da Redinha, Concelho de Pombal, "Boletim da Sociedade Archeològica Santos Rocha", T. I, Figueira da Foz, p. 215-216.

ROCHA, A. dos S., 1908c - Estação Luso-Romana de Roda. "Boletim da Sociedade Archeològica Santos Rocha", T. I, n. ${ }^{\circ}$ 7, Figueira da Foz, p. 247-248.

SAA, M. 1956 - As grandes vias da Lusitânia. O Itinerário de Antonino Pio Voi. II, p. 188 a 197.

SAVORY, H. N.. 1968 - Espanha e Portugal. Ed. Verbo, Lisboa, n. ${ }^{\circ} 14$. 


\section{INVENTÁRIO DAS ESTAÇÕES}

\section{Pelonía}

Folha n. $^{\circ} 262$ P: 4430,9; M: 535,5. Altitude: $40 \mathrm{~m}$

Descrição: Terreno plano situado na margem direita da Ribeira do

Ourão.

Conservação: Ameaçado; abertura de estrada recentemente.

Cronologia: Indeterminado e romano.

Bibliografia: Inédito.

\section{Contabilização:}

\section{Designação}

Cerâmica bordos

Cerâmica tegulae

Debitagem quartzite

Utensílios sílex

Debitagem sílex

Nuclei sílex
Quantidade

2

7

2

27

5

43

Observações: Apesar da uniformidade e homogeneidade do material litico aqui recolhido não é possível precisar a cronologia dos sílices.

\section{Gruta do Ourão}

Folha n. ${ }^{\circ} 262$ P: 4430,8; M: 535,9. Altitude: 63 m

Descrição: Maciço que cobre as Grutas I e II do Ourão.

Conservação: Ameaçado; terreno preparado para pinhal.

Cronologia: Paleolítico Superior. Pré-história Recente.

Bibliografia: Ribeiro (1982); Cordeiro (1984). 
Contabilização:
Designação

Cerâmicas panças

Debitagem quartzite

Nuclei quartzite

Debitagem quartzo

Utensílios sílex

Debitagem sílex

\section{Quantidade}

$\begin{array}{r}13 \\ 1 \\ 4 \\ 2 \\ 17 \\ \hline 37\end{array}$

Observações: Os materiais líticos encontrados aqui apresentam fortes semelhanças com os objectos líticos provenientes de Ourão I; a escavação permitirá esclarecer as relações entre os dois locais dos achados. Em Ourão II alguns vestígios osteológicos encontram-se desprotegidos.

\section{Roda}

Folha n. $^{\circ} 262$ P: 4428,1; M: 536,15. Altitude: $55 \mathrm{~m}$ Cronologia: Romano.

Bibliografia: Alarcão (1982); Cordeiro (1984); Rocha (1908).

Observações: Não realizámos prospecção neste local bem assinalado na bibliografia.

Cordeiro (1984), p. 163-179 leu muita bibliografia sobre os achados aqui feitos. Remetemos para as obras citadas pela A. Visitou o local, tendo encontrado: tegulae e imbrices, lateres, muros de tanques revestidos a opus caementicium, uma mó de $43 \mathrm{~cm}$ de diâmetro. Recolheu pondera, estando estes de posse do Presidente da Junta de Freguesia.

\section{Vale da Sor sa}

Folha n. $^{\circ} 262$ P: 4429,5; M: 538,1. Altitude: $210 \mathrm{~m}$ Descrição: Estrada recentemente aberta: início da descida para Alvito. 
Conservação: Ameaçado pela construção da estrada apenas rasgada agora.

Cronologia: Indeterminado.

Bibliografia: Inédito.

Contabilização:

Designação

Debitagem sílex

Quantidade

1

1

Observações: O achado de um só objecto arqueológico pode dever-se ao estado dos terrenos que envolvem a estrada: matos. A continuação dos trabalhos pode trazer à luz outros vestígios.

\section{Redinha}

Folha n. 262 P: 4428,8; M: 536,45. Altitude: 100 m

Descrição: Encosta calcária, não lavrada, daí o reduzido número de achados.

Conservação: Não ameaçado.

Cronologia: Indeterminado, romano.

Bibliografia'. Inédito.

\section{Contabilização:}

Quantidade

Cerâmica tegulae

Debitagem sílex

Nuclei sílex
1

1

2

Observações: O material litico é apenas constituído por duas peças em sílex que, não sendo fósseis directores, não permitem classificação cronológica. Dos vestígios romanos apenas algumas tegulae. 


\section{Ahito}

Folha n. $^{\circ} 262$ P: 4428,8; M: 537,5. Altitude: $170 \mathrm{~m}$

Descrição: Encosta a NW da aldeia. Terrenos de vinha e estradas.

Jazida de sílex.

Conservação: Ameaçado o local que contém abundantes tegulae: estrada.

Cronologia: Paleolítico Inferior e Médio. Romano.

Bibliografia: Inédito.

\section{Contabilização:}

Designação

Cerâmica tegulae

Utensílios sílex

Debitagem sílex

Nuclei sílex

\section{Quantidade}

6

52

1

59

Observações: Os materiais do Paleolítico encontram-se na vinha, não ameaçados. As tegulae, ao contrário, encontram-se abundantemente no local onde passam as estradas: a antiga e a recentemente rasgada. A destruição está, assim, em curso.

\section{Caeiros dos Algarves}

Folha n. $^{\circ} 262$ P:*; M:*. Altitude:*

Descrição: "Silo" escavado na rocha.

Cronologia: Indeterminado.

Bibliografia: Cordeiro (1984); Rocha (1908a).

Observações: Rocha (1908): A notícia da descoberta de um "silo" levou este autor a deslocar-se à Redinha. Ainda pôde ver um "silo" aberto na rocha (calcário brando). Este foi descrito como sendo um "silo" de gran-

* O local não foi por nós prospectado; por incerteza da localização exacta, ele figura na nossa carta na área urbana da sede de freguesia. 
des dimensões $(80 \mathrm{~cm}$ de diâmetro da abertura; $500 \mathrm{~cm}$ de diâmetro do fundo; $450 \mathrm{~cm}$ de profundidade total). Ainda encontrou alguns ossos provenientes do interior, de que destacamos um húmero humano, imaturo. Não efectuámos prospecções no local, que Cordeiro (1984), p. 184, diz não ter podido encontrar. Pensamos, porém, que ele poderá ter sido simplificado e corresponder ao topónimo Caeiro que ainda consta da carta militar de 1947, junto ao geodésico da Redinha.

\section{Alvito}

Folha n. $^{\circ} 262$ P: 4428,4; M: 537,1. Altitude: $150 \mathrm{~m}$

Descrição: Campo lavrado a E. do povoado do Alvito.

Conservação: Campo onde a lavra não parece ser ameaça para a jazida arqueológica.

Cronologia: Paleolítico Inferior e Médio.

Bibliografia: Inédito.

\begin{tabular}{llc} 
Contabilização: & \multicolumn{1}{c}{ Designação } & Quantidade \\
& Debitagem quartzite & 1 \\
& Nuclei quartzite & 1 \\
& Utensílios sílex & 8 \\
Debitagem sílex & 39 \\
& Nuclei sílex & 7
\end{tabular}

Observações: Boa concentração de materiais em sílex. Uma lavra mais profunda pode pôr em risco a estação arqueológica.

\section{Monte do Meio}

Folha n. $^{\circ} 262$ P: 4427,7; M: 538,25. Altitude: $260 \mathrm{~m}$ Descrição: Encosta E. da falésia da S. rada Estrela.

Conservação: Não ameaçado pois a lavra é feita à enxada.

Cronologia: Indeterminado.

Bibliografia: Inédito. 
Contabilização:

$$
\begin{aligned}
& \text { Designação } \\
& \text { Debitagem sílex }
\end{aligned}
$$

Quantidade

3

Observações: A escassez dos objectos líticos aqui encontrados não permite uma classificação cronológica precisa. Os terrenos envolventes não são cultivados, o que deve estar na origem da dificuldade de se encontrar mais material.

10. Monte do Meio

Folha n. ${ }^{\circ} 262$ P: 4427,6; M: 535,8. Altitude: 240 m

Descrição: Encosta W. do Monte do Meio. Depósito de cascalho.

Jazida de sílex.

Conservação: Não ameaçado.

Cronologia: Indeterminado.

Bibliografia: Inédito.

Contabilização:

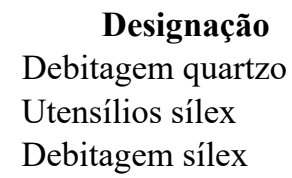

Designação

Debitagem quartzo

Utensílios sílex

Debitagem silex

\author{
Quantidade \\ 1 \\ 2 \\ 3
}

6

Observações: Apenas se encontraram algumas lascas em sílex. Atribuição cronológica mais precisa impossível.

11. Terras do Alcaide

Folha n. ${ }^{\circ} 262$ P: 4427,3; M: 537,3. Altitude: $199 \mathrm{~m}$

Descrição: Encosta W. do Monte do Meio. Terreno ocupado por matos.

Conservação: Não ameaçado actualmente.

Cronologia: Romano.

Bibliografia: Inédito. 
Contabilização:

\author{
Designação \\ Cerâmica tegulae
}

\title{
Quantidade
}

Observações: Prospecção difícil pela existência de matos muito abundantes.

\section{Poios}

Folha n. 262 P: 4427, 0; M: 538, 1. Altitude: $250 \mathrm{~m}$

Descrição: Junto de um lapiás a E. do povoado.

Conservação: O local não parece ameaçado por construções actuais.

Cronologia: Romano.

Bibliografia: Inédito.

Observações: No local apenas encontrámos fragmentos de tegulae.

\section{Vale do Poio Novo}

Folha . $^{\circ} 262$ P: 4425,9; M: 538,1. Altitude: 140 m

Descrição: Vertente N. da estrada W. do Vale do Poio. Jazida de sílex.

Conservação: O local não parece ameaçado actualmente; terra não cultivada.

Cronologia: Paleolítico Antigo e Médio.

Bibliografia: Inédito.

\section{Contabilização:}

\section{Designação}

Utensílios quartzite

Quantidade

Debitagem quartzite

14

Utensílios quartzo

34

Debitagem quartzo

Nuclei quartzo

Utensílios sílex

Debitagem sílex 
14. Vale do Poio Novo

Folha n. ${ }^{\circ} 262$ P: * M: * Altitude: *

Descrição: Materiais provenientes de toda a vertente N. do vale.

Conservação: Poisio, pastagens.

Cronologia: Indeterminado; Pré-história Recente.

Bibliografia: Inédito.

\section{Contabilização:}

$\quad$ Designação
Cerâmica bordos
Cerâmica decorações
Cerâmica panças
Machados polidos
Debitagem quartzite
Utensílios sílex
Debitagem sílex
Nuclei sílex

\begin{tabular}{c} 
Quantidade \\
2 \\
$\mathbf{1}$ \\
55 \\
2 \\
5 \\
$\mathbf{1}$ \\
5 \\
$\mathbf{1}$ \\
\hline
\end{tabular}

72

Observações: A encosta N. do Vale forneceu diversos tipos de materiais: Uticos e cerâmicas. Estas são sempre constituídas por pequenos fragmentos incaracterísticos, por vezes manifestamente recentes. Dentre os achados Uticos destacamos um machado de pedra polida e fragmento doutro.

* Os achados aqui considerados não provêm de um local preciso: foram recolhidos ao longo de toda a vertente N. do vale.

\section{Vale do Poio Novo}

Folha n. ${ }^{\circ} 262$ P: 4426,0; M: 538,5. Altitude: $300 \mathrm{~m}$ Descrição: Abrigo sob rocha na vertente N. do vale. Conservação: Local não ameaçado.

Cronologia: Indeterminado.

Bibliografia: Inédito.

Contabilização:

\section{Quantidade}

1

2 
Observações: Abrigo situado no $5{ }^{\circ}$ nível geològico do vale (nível 1 é o leito do curso de água temporário). Camada de sedimento muito concrecionada e pouco espessa cobrindo parcialmente o chão do abrigo.

16. Buraca Grande, V. do Poio Novo

Folha n. ${ }^{\circ} 262$ P: 4425,5; M: 538,65. Altitude: $270 \mathrm{~m}$

Descrição: Gruta da vertente N. do Vale; $4 .^{\circ}$ conjunto litològico, bem situada.

Conservação: Ameaçado.

Cronologia: Paleolítico Superior. Pré-história Recente.

Bibliografia'. Inédito.

Contabilização:

$\begin{array}{lc}\quad \text { Designação } & \text { Quantidade } \\ \text { Cerâmica asas } & 1 \\ \text { Cerâmica bordos } & 8 \\ \text { Cerâmica fundos } & 2 \\ \text { Cerâmica decorações } & 1 \\ \text { Cerâmica panças } & 12 \\ \text { Conchas marinhas } & \\ \text { Hematite } & \\ \text { Ossos humanos } & \\ \text { Ossos fauna } & \\ \text { Utensílios quartzite } & 8 \\ \text { Debitagem quatzite } & 4 \\ \text { Nuclei quartzite } & 1 \\ \text { Utensílios quartzo } & 2 \\ \text { Debitagem quartzo } & 29 \\ \text { Nuclei quartzo } & 3 \\ \text { Utensílios sílex } & 9 \\ \text { Debitagem sílex } & 51 \\ \text { Nuclei sílex } & 6\end{array}$

137

Observações: Gruta que oferece boas condições de habitat; muito frequentada por pastores, rebanhos e caçadores, encontra-se também ameaçada porque fornece terra "fértil para batatas". Na área revolvida, o paleossolo está bem visível, à mercê dos frequentadores.

Conimbriga, 29 (1990), 5-37 
17. Vale do Poio Novo

Folha n. ${ }^{\circ} 262$ P: 4425, 9; M: 538, 2. Altitude: $170 \mathrm{~m}$

Descrição: Depòsito de cascalho na vertente N. do Vale.

Conservação: Local não ameaçado.

Cronologia: Indeterminado.

Bibliografia: Inédito.

Contabilização:

\section{Designação}

Utensílios quartzite

Debitagem quartzite

Utensílios sílex

Debitagem sílex

Quantidade
1
3
2
8

14

Observações: A prospecção nestes depósitos de cascalho é difícil; o material apresenta-se muito rolado. Neste caso, os vestígios líticos não são suficientemente abundantes para propor uma cronologia mais precisa.

\section{Vale do Poio Novo}

Folha n. $^{\circ} 262$ P: 4425, 85; M: 538, 6. Altitude: $150 \mathrm{~m}$

Descrição: Abrigo sob rocha situado no segundo nível geológico do vale.

Conservação: Ameaçado se não de destruição, pelo menos de voltar a ser algo de grafitos.

Cronologia: Indeterminada.

Observações: $\mathrm{O}$ abrigo apresenta gravuras rupestres de cronologia indeterminada, nesta fase preliminar do trabalho. As reavivagens de parte dos motivos dificultam a "leitura" dos mesmos e o tipo de levantamento agora efectuado não permite qualquer interpretação. Limitando-nos a noticiar e cartografar o achado. Dedicamos-lhe, no entanto, o capítulo IV. 
19. Buraca Escura V. do Poio Novo

Folha n. ${ }^{\circ} 262$ P: 4425, 8; M: 538, 45. Altitude: 300 m

Descrição: Gruta da vertente $\mathrm{S}$. do Vale; $4 .^{\circ}$ conjunto litològico.

Conservação: Local ameaçado.

Cronologia: Indeterminada.

Bibliografia: Inédita.

Observações: Nesta gruta não se encontram, até agora, quaisquer vestígios arqueológicos. Os achados são de natureza osteológica e, de entre os fragmentos característicos, apenas pudemos identificar restos de fauna. Ainda que não tenhamos tido a oportunidade de mostrar os dentes e ossos aqui encontrados a um paleontólogo, foi-nos possível distinguir grandes e pequenos herbívoros, bem como omnívoros e carnívoros. Isto permite-nos considerar que há, aqui, uma jazida paleontológica interessante.

\section{Outeiro de Já Vou}

Folha n. ${ }^{\circ} 262$ P: 4425, 75; M: 537, 15. Altitude: $160 \mathrm{~m}$

Descrição: Vertente W. do Outeiro, estrada rasgada recentemente.

Conservação: Local ameaçado.

Cronologia: Pre-história Recente.

Bibliografia: Inédito.

\section{Contabilização:}

\section{Quantidade}

Cerâmica bordos

Cerâmica fundos

Cerâmica decorações

Cerâmica panças

Machado polido

Percutor

Utensílios quartzite

Debitagem quartzite

4
1
' 1
83
1
1
1
1

93 
Observações: $\mathrm{Na}$ área preparada para plantação de pinheiros e onde passa a estrada. Grande abundância de materiais arqueológicos, sobretudo em cerámicas que, sendo muito grosseiras, são também muito semelhantes entre si. A escavação permitirá interpretar o sítio.

\section{Outeiro de Já Vou}

Folha n. $^{\circ} 262$ P: 4425, 6; M: 537, 9. Altitude: $170 \mathrm{~m}$

Descrição: Vertente E. do Outeiro, estrada rasgada recentemente.

Conservação: Local ameaçado.

Cronologia: Paleolítico Antigo e Médio. Pré-história Recente.

Bibliografia: Inédito.

\section{Contabilização:}

$\quad$ Designação
Percutores
Utensílios quartzite
Debitagem quartzite
Nuclei quartzite
Utensílios quartzo
Debitagem quartzo
Nuclei quartzo
Utensílios sílex
Debitagem sílex
Nuclei sílex

Quantidade
3
46
225
14
2
5
1
18
30
2

346

Observações: $\mathrm{Na}$ área preparada para plantação de pinheiros e onde passa a estrada. Grande abundância de materiais arqueológicos, sobretudo do Paleolítico. A escavação poderá trazer à luz outros elementos de maior interesse para melhor compreensão dos níveis de ocupação.

\section{Outeiro de Já Vou}

Folha n. $^{\circ} 262$ P: 4425, 35; M: 537, 4. Altitude: $170 \mathrm{~m}$

Descrição: Vertente E. do Outeiro, estrada rasgada recentemente.

Conimbriga, 29 (1990), 5-37 
Conservação: Local ameaçado.

Cronologia: Paleolítico Antigo e Médio. Pré-história Recente.

Bibliografia: Inédito.

$\begin{array}{cc}\text { Contabilização: Designação } & \text { Quantidade } \\ \text { Cerâmica bordos } & 2 \\ \text { Cerâmica fundos } & 2 \\ \text { Cerâmica decorações } & 1 \\ \text { Cerâmica panças } & 95 \\ \text { Utensílios quartzite } & 44 \\ \text { Debitagem quartzite } & 56 \\ \text { Nuclei quartzite } & 8 \\ \text { Utensílios quartzo } & 1 \\ \text { Debitagem quartzo } & 1 \\ \text { Nuclei quartzo } & \\ \text { Utensílios sílex } & 4 \\ \text { Debitagem sílex } & 8 \\ \text { Nuclei } \text { sílex } & \end{array}$

Observações: $\mathrm{Na}$ área preparada para plantação de pinheiros e onde passa a estrada. Grande abundância de materiais arqueológicos, sendo a cerámica homogénea e grosseira. Dentre o material litico, a série antiga encontra-se muito rolada e patinada.

\section{Outeiro de Já Vou}

Folha n. $^{\circ} 262$ P: 4425,5; M: 537,6. Altitude: 210 m

Descrição: Vertente W. do Outeiro, estrada rasgada recentemente.

Conservação: Local ameaçado.

Cronologia: Paleolítico Antigo e Médio. Pré-história Recente.

Bibliografia: Inédito. 
Contabilização:

$\quad$ Designação
Cerâmica bordos
Cerâmica panças
Machado polido
Percutor
Utensílios quartzite
Debitagem quartzite
Nuclei quartzite
Utensílios sílex
Debitagem sílex

\begin{tabular}{c} 
Quantidade \\
2 \\
23 \\
1 \\
1 \\
1 \\
29 \\
1 \\
2 \\
8 \\
\hline
\end{tabular}

68

Observações: $\mathrm{Na}$ área preparada para plantação de pinheiros, os materiais arqueológicos são em menor abundância que nas estações arqueológicas vizinhas; mas as diferentes séries recolhidas apresentam-se consideravelmente homogéneas entre si.

24. Outeiro de Já Vou

Folha n. ${ }^{\circ} 262$ P: 4425,2; M: 537,45. Altitude: $180 \mathrm{~m}$

Descrição:

Conservação: Ameaçado.

Cronologia: Paleolítico Antigo e Médio; Pré-história Recente.

Bibliografia: Inédito.

\section{Contabilização:}

Designação

Cerâmica asas

Cerâmica bordos

Cerâmica panças

Debitagem quartzite

Nuclei quartzite

Nuclei sílex

Machado Polido

Percutores
Quantidade

i

i

28

75

23

1

1

2

132

Conimbriga, 29 (1990), 5-37 


\section{Passada Má}

Folha n. $^{\circ} 262$ P: 4425, 1; M: 537, 85. Altitude: 220 m

Descrição: Vertente W. do Outeiro, estrada rasgada recentemente.

Conservação: Ameaçado.

Cronologia: Pré-história Recente.

Bibliografia: Inédita.

\section{Contabilização:}

$\quad$ Designação
Cerâmica pansas
Debitagem quartzite
Nuclei quartzite
Debitagem sílex
Nuclei sílex

Quantidade
4
17
1
3
1

Observações: Área preparada para plantação de pinheiros, sendo os materiais arqueológicos pouco abundantes. A escavação poderá fornecer outros elementos mais esclarecedores do tipo de estação arqueológica aqui assinalada.

\section{Vale do Poio Velho}

Folha n. $^{\circ} 262$ P: 4424, 75; M: 538, 25. Altitude: $340 \mathrm{~m}$ Descrição: Vertente N. do Vale, gruta pequena e plataforma de sedimentos.

Conservação: Local não ameaçado.

Cronologia: Indeterminado.

Bibliografia: Inédita.

\section{Contabilização:}

\section{Designação \\ Debitagem quartzite \\ Debitagem quartzo}

\section{Quantidade \\ 2 \\ 1}

3

Observações: A gruta, resultante do alargamento de uma falha natural, está sobranceira a pequena plataforma de sedimentos concrecionados onde se encontraram vários fragmentos quartzíticos talhados. 
27. Corte

Folha n. $^{\circ} 262$ P: 4424, 8; M: 538, 5. Altitude: 350 m

Descrição: Vertente S. da Cabeça da Corte.

Conservação: Local não ameaçado.

Cronologia: Pré-história Recente.

Bibliografia: Inédito.

Observações: Pequeno campo lavrado onde apenas se encontrou um fragmento de machado polido. O local merece uma prospecção mais aturada.

28. Vale do Poio Velho

Folha n. $^{\circ} 262$ P: 4424, 6; M: 538, 3. Altitude: 320 m

Descrição: Vertente N. do vale, depósito de cascalho.

Conservação: Local ameaçado.

Cronologia: Paleolítico Antigo e Médio.

Bibliografia: Inédito.

Contabilização:

\author{
Designação \\ Debitagem calcário \\ Debitagem quartzite \\ Debitagem quartzo
}

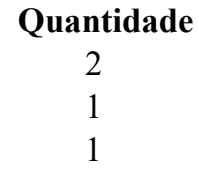

4

Observações: Prospecção difícil no depósito de vertente. Os materiais arqueológicos encontram-se misturados com o cascalho anguloso. É difícil avançar hipóteses sobre a origem exacta destes materiais bem como explicar por que se encontram misturados com o cascalho. 
29. Lapa de Jagardo

Folha n. $^{\circ} 262$ P: 4423, 8; M: 536, 28. Altitude: $220 \mathrm{~m}$

Descrição: Sobre o montículo onde existe a gruta. Terreno não lavrado.

Conservação: Local não ameaçado.

Cronologia: Indeterminado.

Bibliografia: Inédito.

Observações: Prospecção que necessita de ser refeita; o facto de os terrenos não serem lavrados dificulta o achado de vestígios. Apenas encontrámos um pequeno sílex talhado, à superfície, nas imediações da gruta. 
(Página deixada propositadamente em branco) 
EST. I

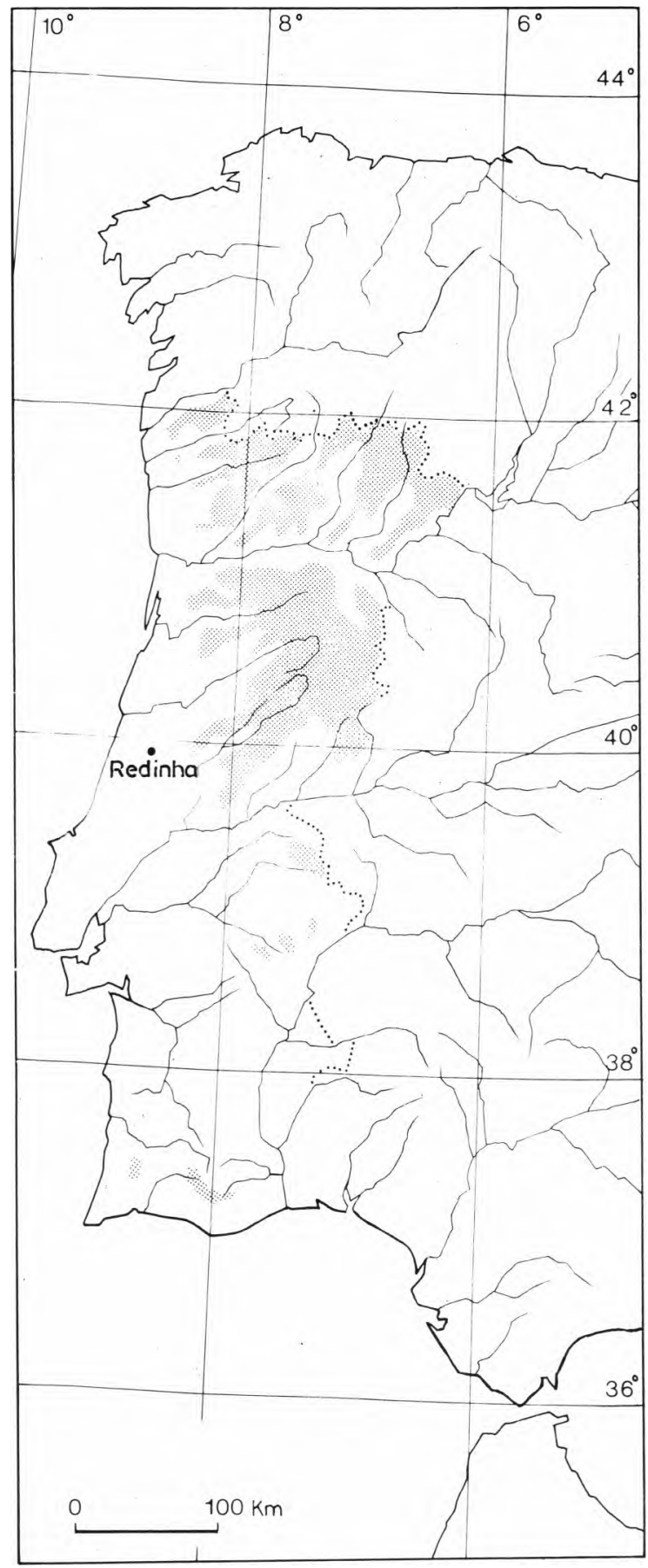


EST. II

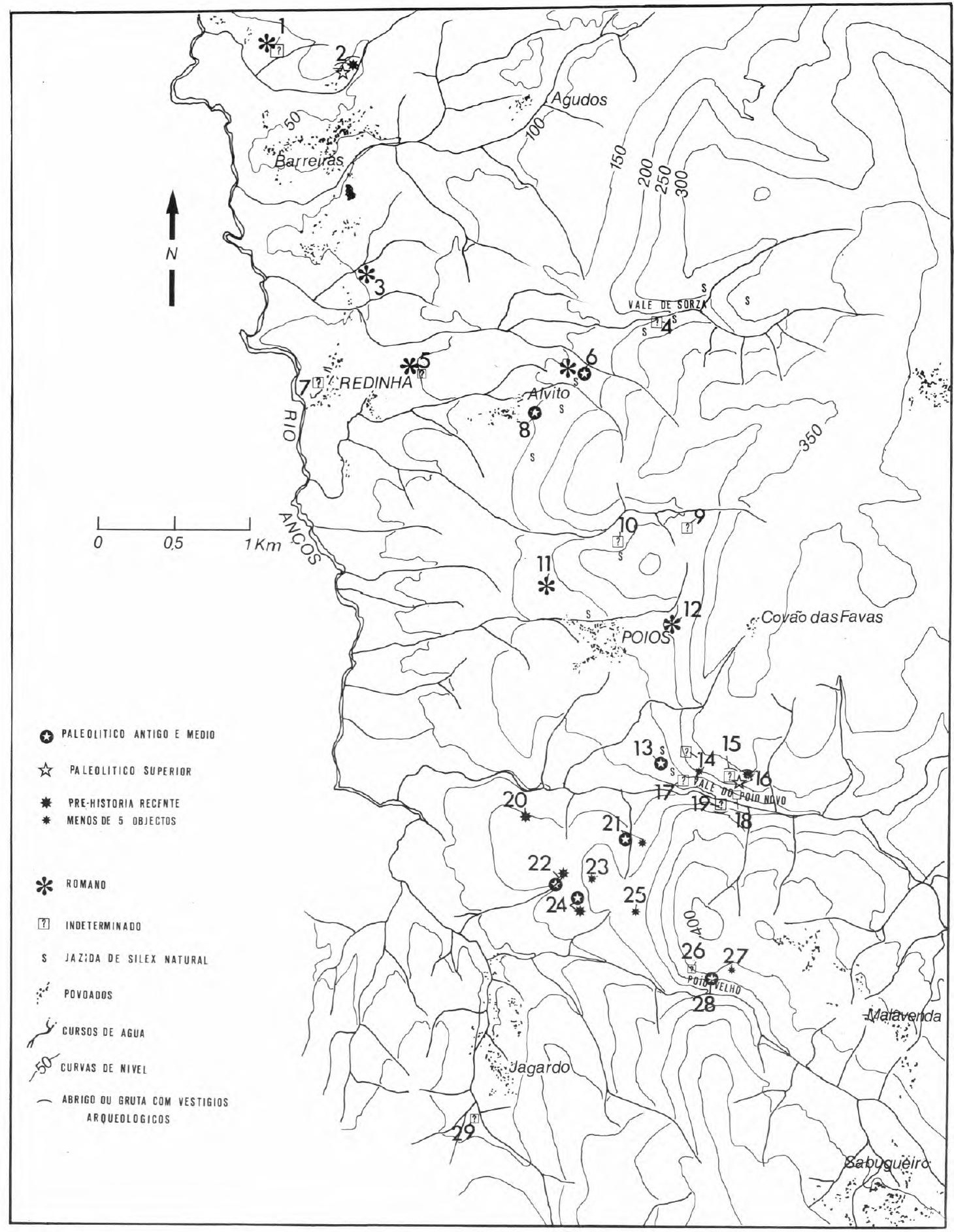


EST. III
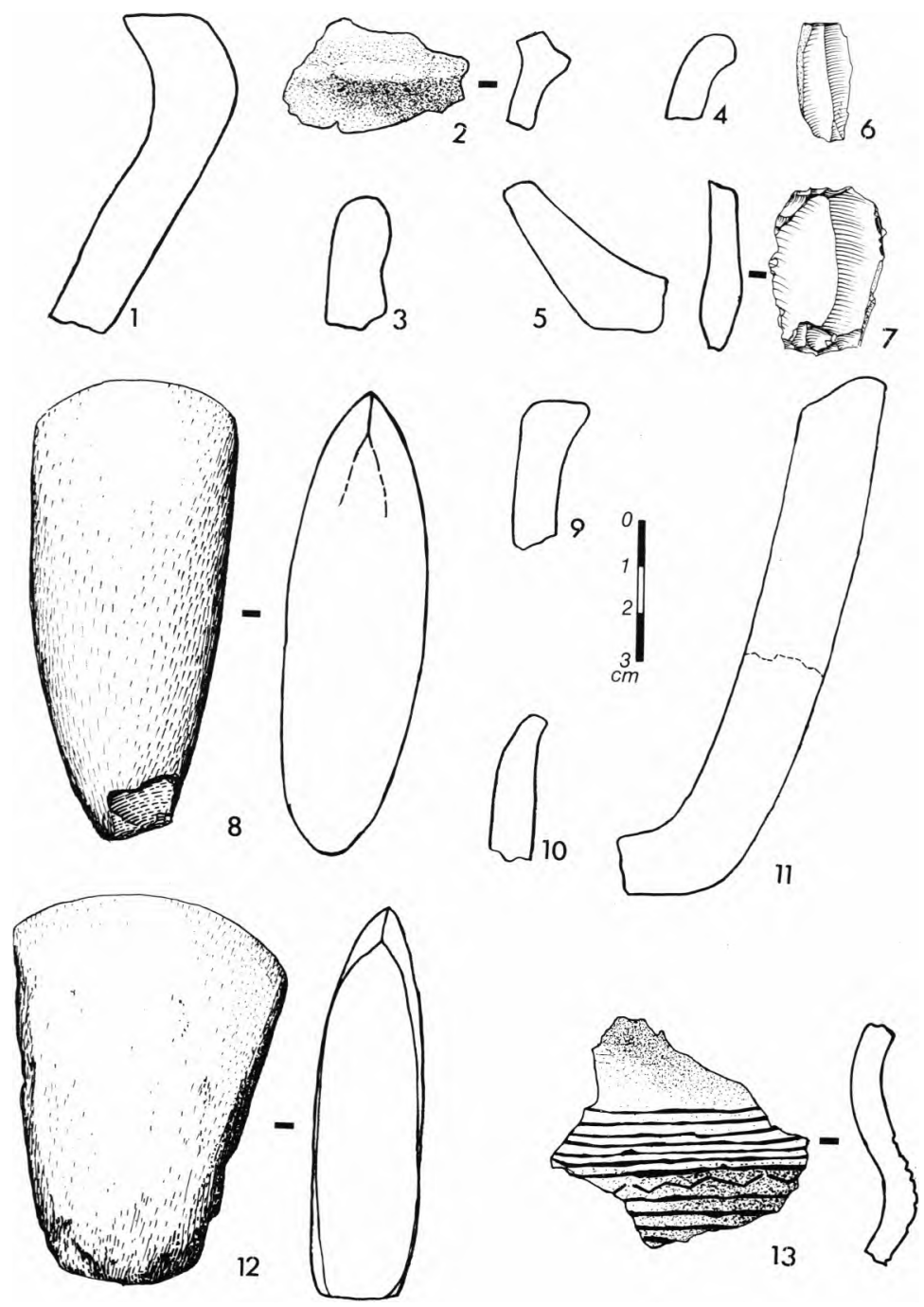
EsT. IV

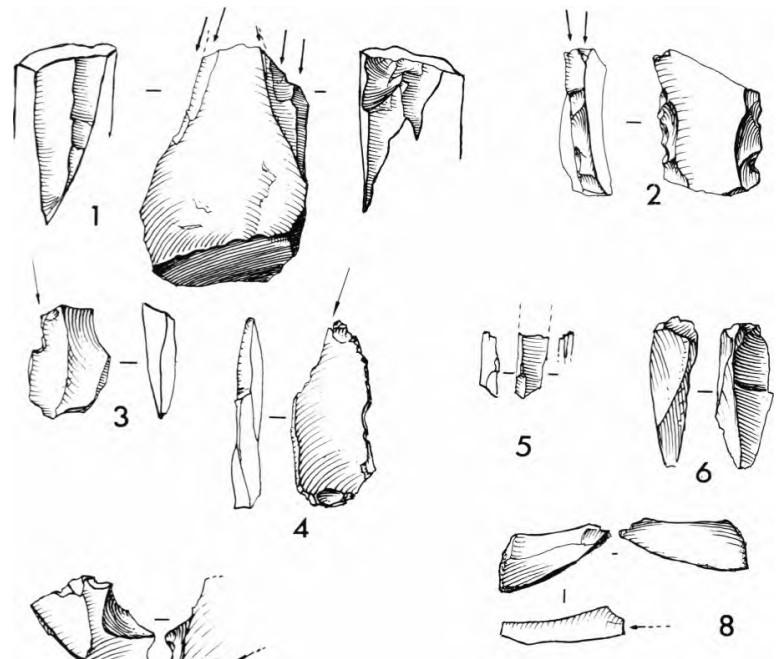

$\underbrace{}_{10}$

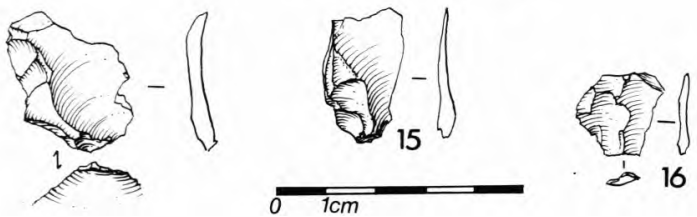

14 
EsT. V
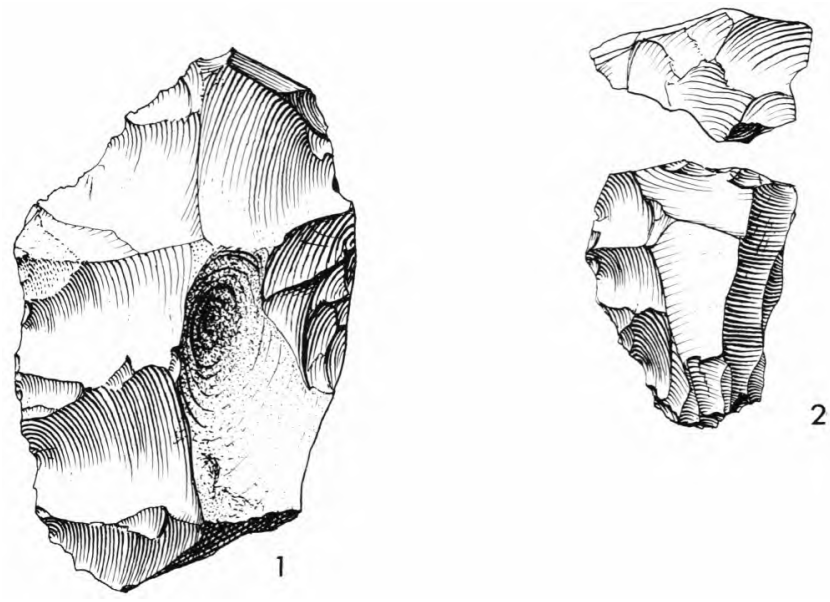
EST. VI

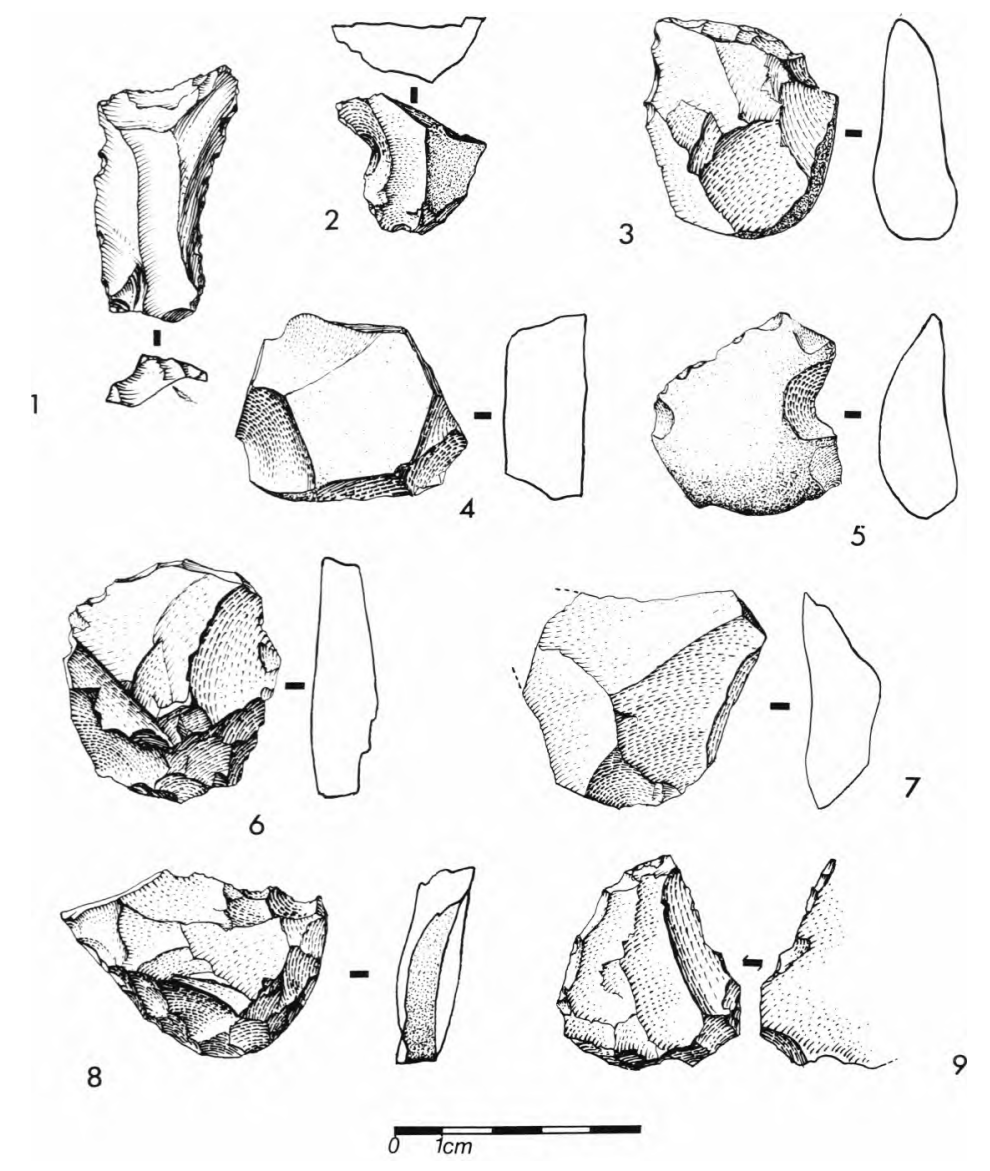


EsT. VII
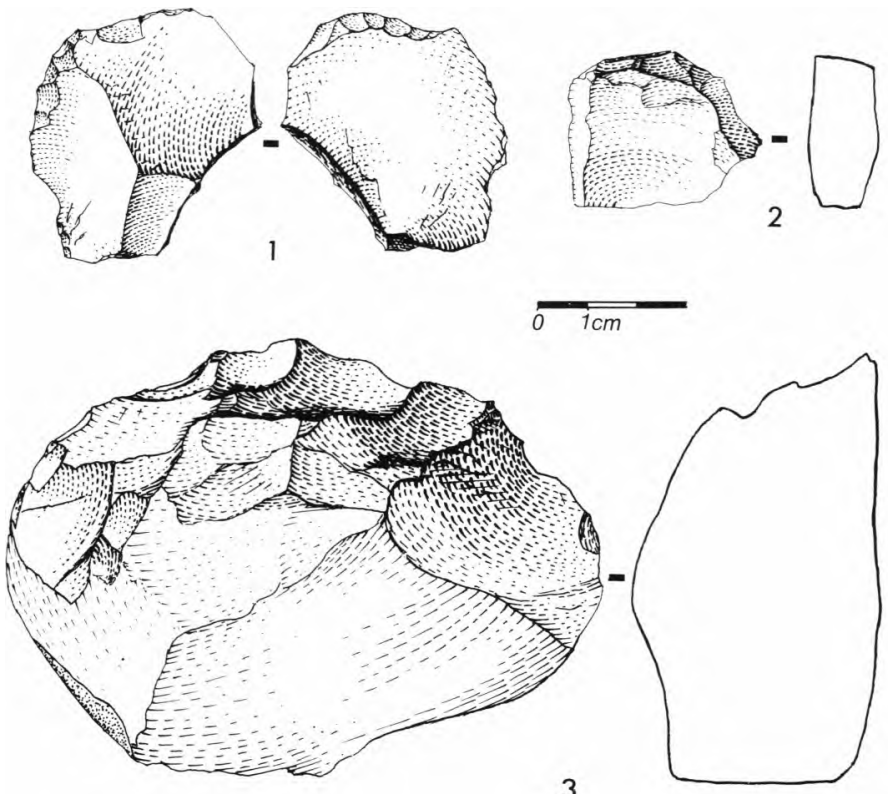

3

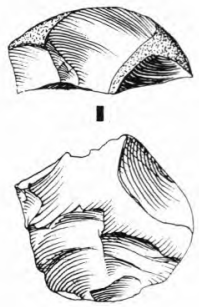

4

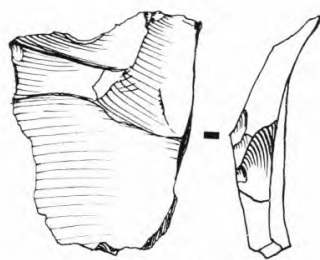

5

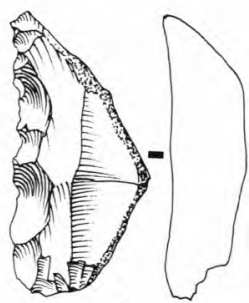

6 
EST. VIII
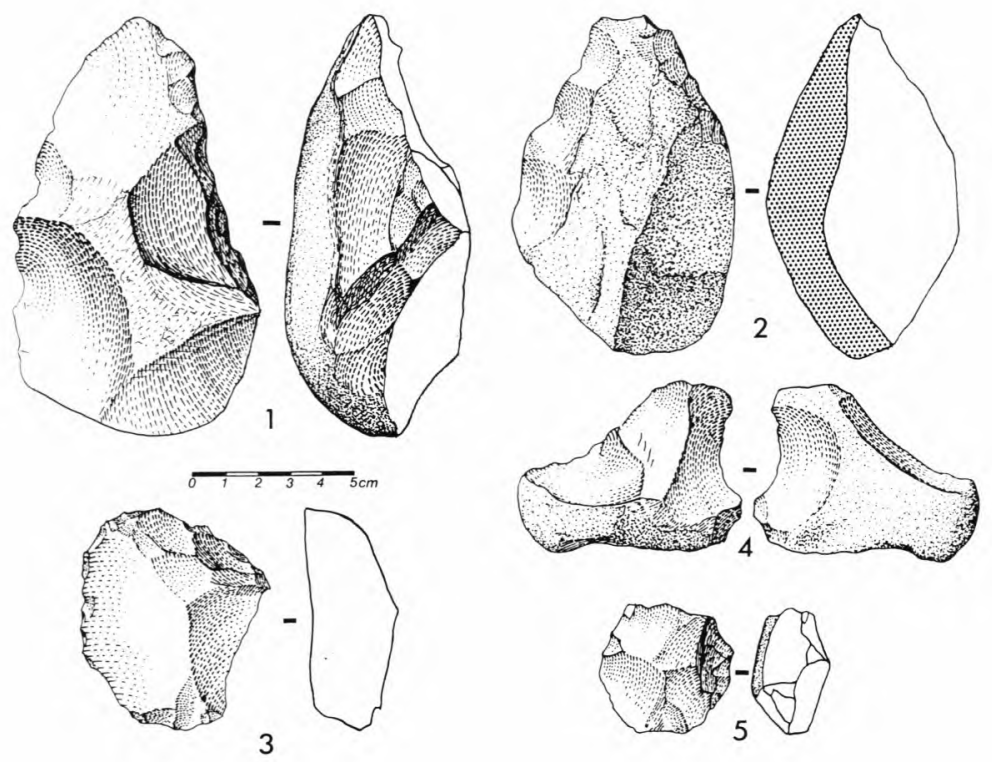
EST. IX

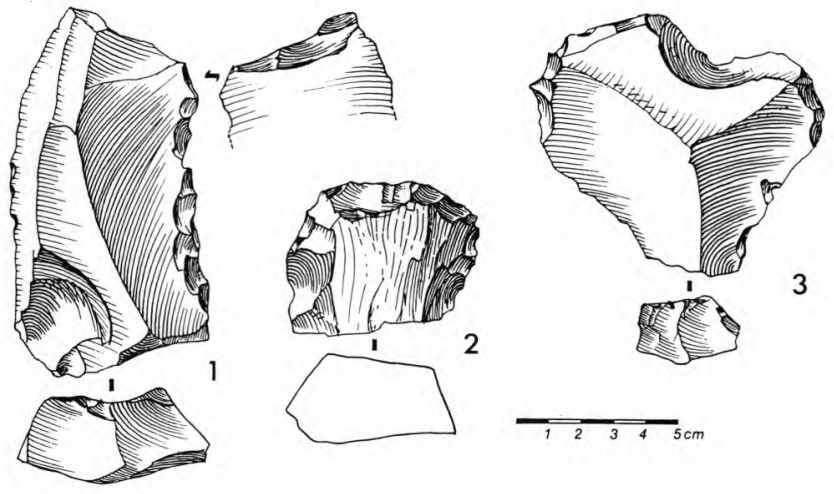


Est. X

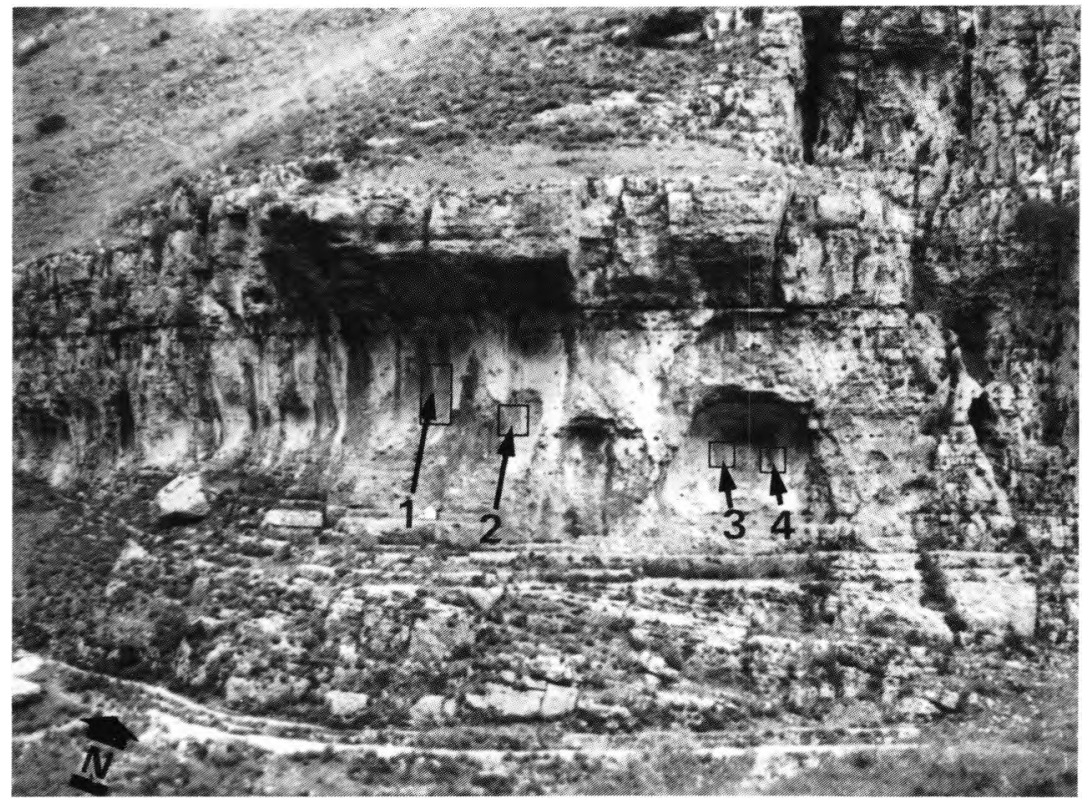


EST. XI

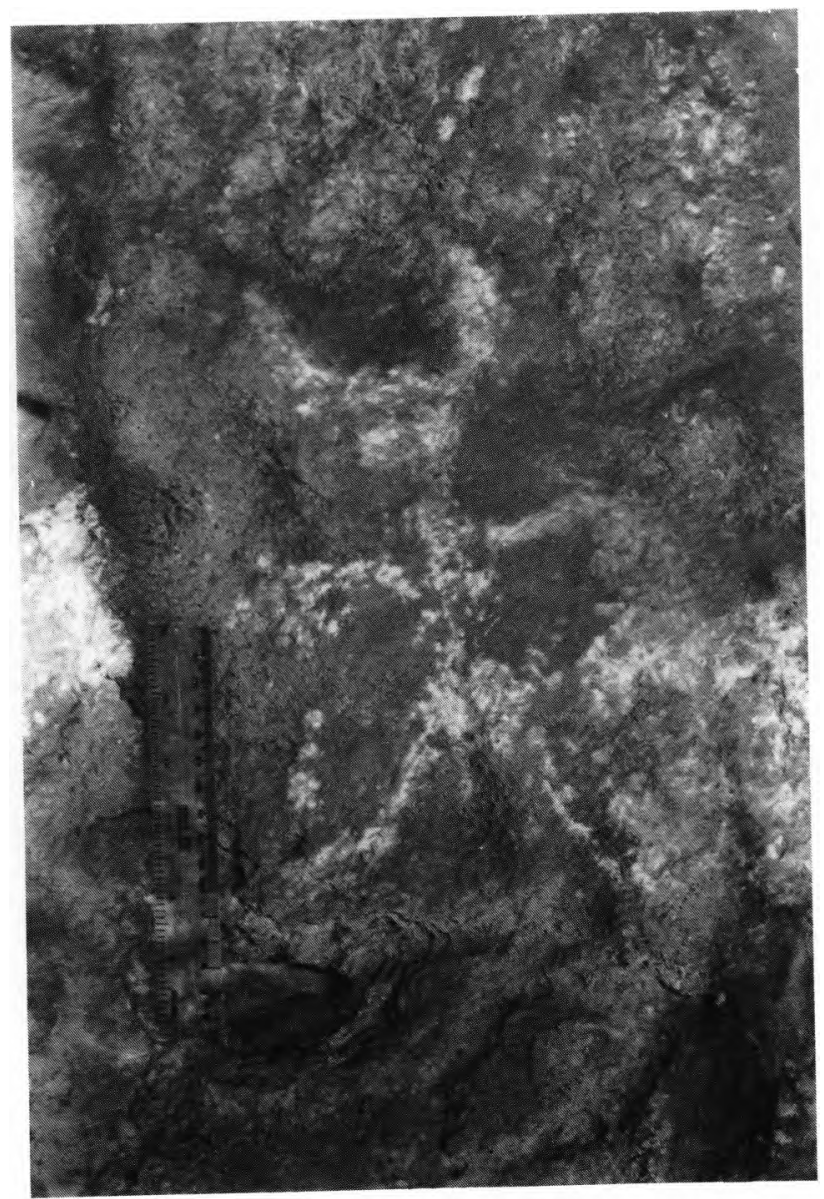

Pormenor da única figura do painel 3 
EsT. XII

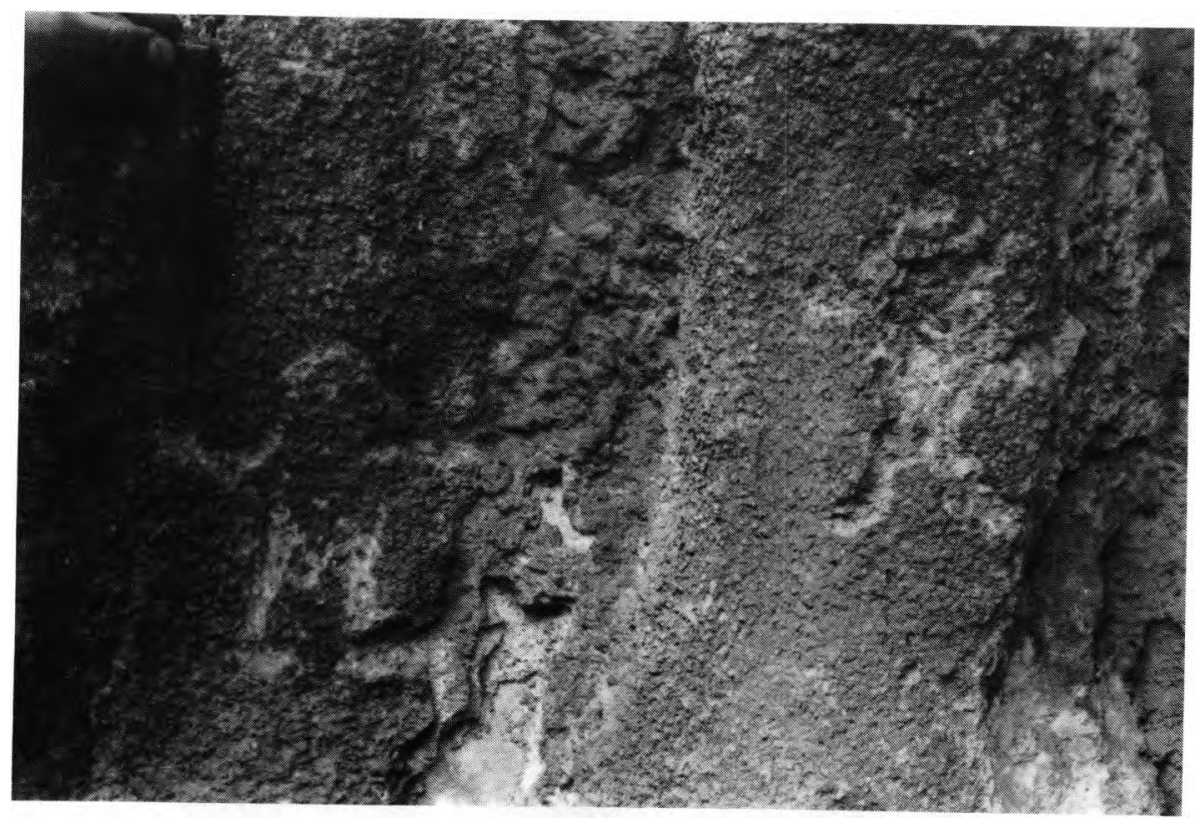

Pormenor do painel 2 
EST. XIII

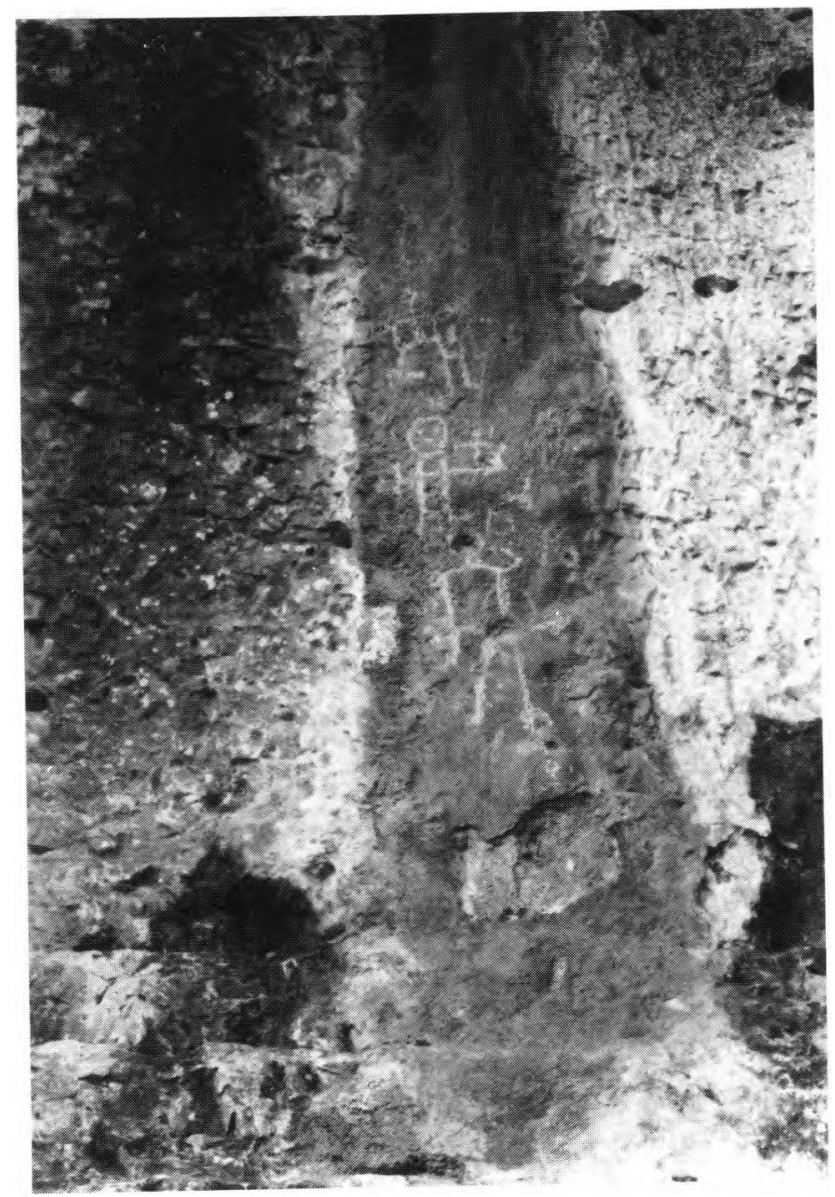

Painel 2 
EST. XIV

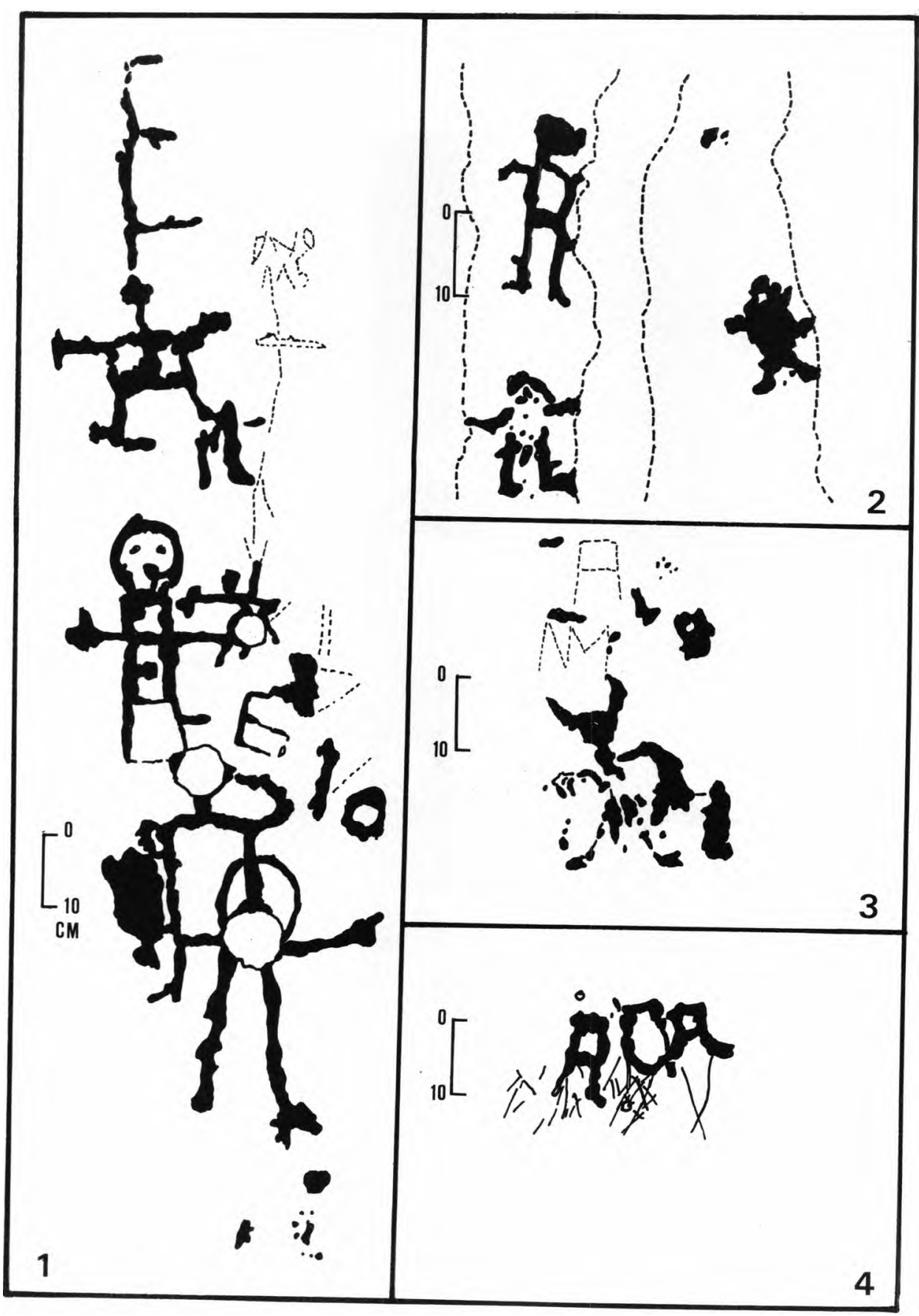

